\author{
Шевченко Лілія Михайлівна, ${ }^{\text {a }}$ \\ кандидат педагогічних наук, доцент Одеської \\ національної музичної академії \\ ім. А. В. Нежданової \\ https//orcid.org/0000-0001-8602-9573 \\ lilia.my.forte@gmail.com
}

\title{
СТИЛЬОВІ ОСОБЛИВОСТІ АНСАМБЛЕВОЇ МУЗИКИ К.СЕН-САНСА У ГРІ ПІАНІСТІВ ОДЕСИ
}

\begin{abstract}
Мета даної роботи - позначити особливості стильового прояву К. Сен-Санса у французькій анасамблевій музиці й органіки осягання ії музикантами Одеси. Методологічною основою роботи є культурологічний підхід у мистецтвознавстві, представлений у тому числі школою Б.Асафьєва в Україні, початки якого зафіксовані французькою Ars nova початку XIV століття й повернені в русло театрального мімезиса Ж.-Ж.Руссо. Базисне місце займає метод жанрово-стильового порівняльного аналізу, герменевтичний, історико-описовий методи, що дозволяють у межах метафізики історії (О.Лосєв, М.Конрад) зафіксувати значеннєві паралелі становлення гуманітарної сфери й виразності мистецтва. Наукова новизна роботи визначена теоретичною самостійністю позначення ансамблевого стилю К. Сен-Санса як протонеобарочного з рисами неорококо, що $є$ співвідноситься зі стильовими перевагами неосимволізму (за О. Марковою) музики кінця XX - початку XXI століть. Також уперше в українському музикознавстві акцентується самостійність музикантів Одеси в освоєнні камерно-інструментальної спадщини К. Сен-Санса, особливо його творів з фортепіанною участю в ансамблі. Висновки. Композитор виявився безпосереднім спадкоємцем салонного інструменталізму, у якому істотною $є$ фортепіанна участь у тім колориті клавірності, що представляє французький стиль фортепіанного мистецтва й живиться естетикою «легких» фортепіано епохи Реставрації. Для цього мистецтва показова антитеатральна манера відсторонення від безглуздостей і грубостей життя заради створення творчого «оазису» художнього служіння Красі. Этюдно-прелюдійна моторика займає провідне положення в техніці вираження, що усвідомлювалося в якості базового творчого показника у виконавському мистецтві музикантів Одеси, яка дала Україні творчий дует піаністів О.і В.Щербакових, ансамбль «Гармонії світу», ін. Останні спеціалізувалися на виконанні музики модерну й просимволістської художньої лінії, в якій твори К. Сен-Санса зіграли значну й самостійну роль.
\end{abstract}

Ключові слова: інструментальна ансамблева музика, традиції виконавства, фортепіанна традиція Одеси, проотонеобароко, неорококо

Шевченко Лилия Михайловна, кандидат педагогических наук, дочент Одесской национальной музыкальной академии имени А. В. Неждановой

Традиции ансамблевой музыки К.Сен-Санса в игре пианистов Одессы

Цель данной работы - обозначить особенности стилевого проявления К.Сен-Санса во французской анасамблевой музыке и органики постижения ее музыкантами Одессы. Методологической основой работы является культурологический подход в искусствознании, представленный в том числе школой Б.Асафьева в Украине, начала которого зафиксированы французской Ars nova начала XIV века и повернуты в русло театрального мимезиса Ж.-Ж.Руссо. Базисное место занимает метод жанрово-стилевого сравнительного анализа, герменевтический, историко-описательный методы, позволяющие в пределах метафизики истории (А.Лосев, Н.Конрад) зафиксировать смысловые параллели становления гуманитарной сферы и выразительности искусства. Научная новизна работы определена теоретической самостоятельностью обозначения ансамблевого стиля К.СенСанса как протонеобарочного с чертами неорококо, что является соотносимым со стилевыми предпочтениями неосимволизма (по Е.Марковой) музыки конца XX - начала XXI столетий. Также впервые в украинском музыковедении акцентируется самостоятельность музыкантов Одессы в освоении камерно-инструментального наследия К.Сен-Санса, особенно его сочинений с фортепианным участием в ансамбле. Выводы. Композитор оказался непосредственным наследником салонного инструментализма, в котором существенно фортепианное участие в том колорите клавирности, который представляет французский стиль фортепианного искусства и питаем эстетикой «легких» фортепиано эпохи Реставрации. Для этого искусства показательна антитеатральная манера отстранения от нелепостей и грубостей жизни ради создания творческого «оазиса» художественного служения Красоте. Этюдно-прелюдийная моторика занимает ведущее положение в технике выражения, которая осознавалась в качестве базового творческого показателя в исполнительском искусстве музыкантов Одессы, давшей Украине творческий дуэт пианистов О.и В.Щербаковых, ансамбль «Гармонии мира», специализировавшихся на исполнении музыки модерна и просимволистской художественной линии, в которой сочинения К.Сен-Санса сыграли значительную и свамостоятельную роль.

Ключевые слова: инструментальная ансамблевая музыка, традиции исполнительства, фортепианная традиция Одессы, проотонеобарокко, неорококо

СШевченко Л. М., 2019 
Shevchenko Lilia, candidate of Pedagogical Sciences, assistant professor Odessa national music academy of the name A.V.Nezhdanova

The Traditions of Ensemble music of C.Saint-Saëns in the play of Pianists of Odesa

The purpose of the article is to mark the particularities a style manifestations C. Saint-Saëns in french ensemble music and naturalness of the understanding her musician Odessa. The methodology of the work is culturology approach in the science of art, presented including school of B.Asafiev in Ukraine, begin which are fixed french Ars nova begin XIV century and are turned in riverbed theatrical mimesis of J.-J. Rousseau. The base place occupies the method of genre-style benchmark analysis, hermeneutic, historian-descriptive methods, allowing within metaphysicians of the histories (A.Losev, N.Konrad) fix the semantic parallels of the formation of the humanitarian sphere and expressiveness to art. The scientific novelty of the work is determined by theoretical independence of the indication of ensemble style to C. Saint-Saëns as protoneobaroque with the devil of neorococo that is correlated with style preferences of neosymbolism (on E.Markova) of the music end XX - begin XXI centuries. Also, for the first time independence musician, Odesa is accented in Ukrainian musicology in mastering chamber-instrumental heritage C. Saint-Saëns, particularly his compositions with piano participation in the ensemble. Conclusions. The composer turned out to be the direct legal successor of salon instrumental art, in which greatly piano participation in that coloring clavier type, which presents the french style piano art and supplies the aesthetics "light" pianoforte of the epoch to Restorations. For this art, meaningful anti-theatric manner of discharge from absurdities and roughnesses to lives for the sake of creation creative "oasis" of artistic serving to Beauty. Étude-prelude mechanics occupies the leading position in technology of the expression, which was realized as base creative factor in performance art to musician of the Odessa, which gave to Ukraine creative duo pianist of O. and V. Shcherbakovs, ensemble of "Harmonies of the world", specialized on performance of the music of the modernist style and symbolism artistic line, in which compositions of C. Saint-Saëns have played a significant and independent role.

Key words: instrumental ensemble music, traditions of performance art, the piano tradition of the Odessa, protoneobaroque, neorococo

Актуальність теми дослідження визначена, по-перше, все зростаючою значимістю у виконавців і публіки творів К. Сен-Санса, а, по-друге, затребуваністю в сучасних умовах ансамблевої культури. Останнє спонукає піаністів-солістів, навіть масштабу М.Аргерих, М.Плетньова, надають перевагу сумісним виступам сольних, що, напевно, продиктовано тенденцією «відчуження» авторського егоцентризму в музичному вираженні, що встановилося в епоху поставангарда як прояву «індекативності» суб'єкт - об'єкт, неможливого в артистичній класиці Європи попередніх сторіч.

Мета даної роботи - позначити особливості стильового прояву К. Сен-Санса у французькій анасамблевій музиці й органіки осягання іï музикантами Одеси. Методологічною основою роботи $\epsilon$ культурологічний підхід у мистецтвознавстві, представлений у тому числі школою Б.Асафьєва в Україні $[1 ; 4$, iн.], початки якого зафіксовані французькою Ars nova початку XIV століття й повернені в русло театрального мімезиса Ж.-Ж.Руссо. Базисне місце займає метод жанрово-стильового порівняльного аналізу, герменевтичний, історико-описовий методи, що дозволяють у межах метафізики історії (О.Лосєв, О.Маркова [2; 4]) зафіксувати значеннєві паралелі становлення гуманітарної сфери й виразності мистецтва. Наукова новизна роботи визначена теоретичною самостійністю позначення ансамблевого стилю К. Сен-Санса як протонеобарочного з рисами неорококо, що $є$ співвідноситься зі стильовими перевагами неосимволізму (за О. Марковою) музики кінця XX - початку XXI століть. Також уперше в українському музикознавстві акцентується самостійність музикантів Одеси в освоєнні камерноінструментальної спадщини К. Сен-Санса, особливо його творів з фортепіанною участю в ансамблі.

Від середини XVIII століття французька художня традиція одержала нові стимули прилучення до процесу інструменталізації музичного професіоналізму, у якому очевидно передував музичний театр, а інструментальна творчість міцно зв'язана була з культурою салону. Багато чого змінилося з фатального 1789 р., коли почалися саме революційні перетворення. У музичному вираженні це проявлялося в посиленому впровадженні німецьких традицій - ідеологи Французької революції піднімали на щит спадщину гугенотів як історичних супротивників королівської влади у Франції. Останніх Людовик XIV 3 певною пошаною (дані були підйомні гроші, всі гугеноти одержали титул баронів) виселив у землі їх побратимів по протестантській вірі - у Швейцарію й Німеччину, щоб запобігти громадянській-релігійній війні, до якої була надзвичайно близькою країна від 24 серпня 1572 р. («Варфоломеєвська ніч»).

Революційний конвент рекомендував писати актуальні тексти на мелодії гугенотських псалмів $[8, \mathrm{c}$. 73], а представник Віденської школи Х.Глюк, одержавши підтримку в прореволюційно орієнтованій «партії королеви», німкені по крові й культурній позиції, активно впроваджував німецьку пропасіонну хорову оперність у музично-театральну практику Франції $1770-\mathrm{x}$ - початку $1780-$ х років.

Такого роду політика «германізації» музики Франції дала свої плоди: у першій половині XIX століття деякі з найбільших представників французької музики - Г.Берліоз, Дж.Мейєрбер - представляли пробетховенский симфонізм в оркестрово-ораторіальній і оперній сфері. Французький інструменталізм, що расцвів в пору становлення й ствердження рококо на чолі з Ф.Купереном Великим, виявився відкинутим. Зусиллями П.Байо, П.Роді, Р.Крейцера висунулася французька скрипкова школа, у якій 
видатний скрипаль і композитор А.Вьєтан визначив самостійний шлях французького інструменталізму в спадкування досягнень Франції попередніх епох. Цьому ж сприяв А.Буалдьє, оперний композитор, доля якого виявилася зв’язаною з Росією, як і доля знаменитого французького балету М.Петіпа.

Франція стала опорою піанізму Реставрації 1813-1848 pp., де в мистецтві «легких» або «флейтових» (оскільки відтворювався колорит звучання флейти-стакато) фортепіано пізнавані були харатерні ознаки одухотвореної салонної творчості сольної клавесинової музики. Тут особливу роль зіграла діяльність двох геніальних виконавців і композиторів: Дж.Фільда й Ф.Шопена, що усвідомлювали себе в представництві французького салонного піанізму.

Однак тільки в другій половині ХІХ століття спостерігається відродження французького інструменталізму в широті жанрового охоплення від камерного мистецтва до філармонічної оркестральності. Як і у випадку скрипкової школи наприкінці XVIII - на початку XIX століття, істотна роль належала тут бельгійській школі: на початку віку романтизму бельгієць Ш.Беріо визначив вихід А.Вьєтана, у другій половині цього ж сторіччя С.Франк зазначив стійкий принцип становлення французької симфонічної й у цілому інструментальної школи, проявом якої, до визнання К.Дебюссі й М.Равеля, виступив К. Сен-Санс.

I С.Франк, і К. Сен-Санс творили в постромантичний період бугтя мистецтва, коли академізація романтизму невідступно становила паралель народжуваному модерну імпресіоністськогосимволістського типу. Сучасниками К. Сен-Санса стали такі композитори як Е.Лало, Е.Шабріє, П.Дюка, Е.Шоссон і багато інших видатних творців інструментальної слави Франції, у творчості яких очевидні були установки на стверджуваний імпресіонізм, у тому числі це знаменитий «Учень Чарівника» П.Дюка, що став класикою імпрресіоністичного «звукопису».

К. Сен-Санс виділяється в зазначеному оточенні своєю причетністю до протоимпрессионизмупротосимволизму, і до що народжується неоклассицистской лінії: його «Лебідь» 3 «Карнавалу тварин» (1886) став емблемою просимволистской палітри, один раз перетворений у сценічний образ «Умираючого лебедя» А.Павловой. А опера Сен-Санса «Самсон і Далила» (1876) упевнено трактується як зразок протонеоклассического твору. Камерна інструментальна музика К. Сен-Санса ввійшла в репертуарний список найбільших виконавців миру, у тому числі це Перший струнний квартет 1899 р., септет для труби, струнного квінтету й фортепіано 18881 р., 3 сонати 1921 р. для гобоя й фортепіано, для кларнета й фортепіано, для фагота й фортепіано [6, с. 920].

Оцінка досягнень К. Сен-Санса в області сонатної творчості не завжди була адекватною. Так, у змістовній і дослідницьки глибокій статті В.Бобровського, присвяченої в 6-титомовій Музичній енциклопедії сонаті, знаходимо такі дивно на сьогодні звучні слова: «Менш значна соната К. Сен-Санса, Й.М.Рейнбергера, К. Синдинга й ін. Спроби відродити в них класичні принципи не дали художньопереконливих результатів» [7, с. 197].

Зазначеним авторам Бобровський протиставляє досягнення М. Регера, В. д’Енді, Е. Мак-Доуелла, К. Шимановського. Таке розходження оцінок зв'язане, зважаючи на все, з підходом дослідника до «невдалих» творів Сен-Санса, Сіндінга й ін. 3 позицій «кризи» сонатного жанру на грані століть, відповідно, має місце наполегливий пошук «неспроможності» сонатних проб в «прокласичних» варіантах. Зачислювані ж Бобровським у романтизм, імпресіонізм-символізм зразки виявляються для нього прийнятними й бажаними. Стилістичні «прикордоння» протонеоклассицизму явно не приймаються зазначеним дослідником.

Однак та «стертість» співвідношень класичного-аклассичного-модерного, котра усвідомлювався як недолік в альтернативних рішеннях середини XX століття, із твердженням полістилістики постмодернапоставанграда на грані XX i XXI вв. приймається як закономірна дифузія стильової еклектики «неосимволізму» (за О.Марковою [4, с. 99-134]). Торжество ж у стилістиці пост- і трансавангарда типологічності полістилістичного принципу вираження приводить до переосмислення оцінок композиторської-авторської творчості, у якій індивідуалізована концепція тематизму й формиархітенктоніки перестала відігравати вирішальну роль в усвідомленні художньої значущості творів. Типологізми «еклектики» епохи символізму кінця XIX - початку XX століття визначилися як джерела тої концептуальності художнього вираження, що восторжествувала із вступом поставангарда 1970-х - 1990-х років.

Відповідно, не тільки символістські відкриття А.Цемлінського, Ф.Шрекера, І.Падеревського, В.Ребикова й ін. були повернуті у творчо затребуваний комплекс художнього досвіду (див. «ренесанс Шрекера», «ренесанс Цемлінського» й ін.[9, с.128, 136]), але також і протонеоклассицизм 3.Носковського, М.Метнера, М. і А.Гречанінових, ін. стали надбанням широкої публіки й ентузіастичної оцінки продукції названих авторів. У цій хвилі концептуалізму кінця ХХ століття одержала широке визнання спадщина К. Сен-Санса, у тому числі його ансамблева музика, настільки відверто недооцінена в період виражених розмежувань авангард - традиціоналізм.

У цілому інструментальна спадщина К. Сен-Санса відзначена спеціальною увагою композитора до камерно-інструментальної специфіки, що визначило спеціальну спрямованість у підсумковому для його 
життя й творчості 1921 р. створення трьох Сонат для гобоя, кларнета й фагота 3 фортепіано як підсумок роботи в камерно-ансамблевій сфері.

Також ігрова добірність музики Сен-Санса, інфантильні зрізи в його образах, що включають у світ людей тварин і біблейських-легендарних персонажів, концертно-ошатний тонус творів, - всією сукупністю зазначених виразних складових мистецтво Сен-Санса переборює спадщину «германізації», що визначилося від революційного часу XVIII в. і романтичних проекцій цього суворого драматизму (Г.Берліоз, Ф.Обер, Дж.Мейербер). I зроблено це на користь апеляцій до «дитячості» рококо і його салонних відтворень в період Реставрації.

До того ж очевидні протонеокласичні тенденції стильової спрямованості творчості Сен-Санса, у якого маємо усвідомлення істотності імпресіоністського-символістського внеску модерну, що сполучався з установками на значимість класичних моделей у їх адаптації до неадекватних умов модерністського художнього середовища. Внесок К. Сен-Санса в мистецтво камерно-інструментальної музики визначено стильовими установками на протонеокласицизм, у якому класичні моделі співвідносяться з наробітками прийомів модерну - у вигляді виразних засобів імпресіонізму-символізму.

Сонати для духових інструментів і фортепіано (для гобоя, кларнета й фагота 3 фортепіано), написані в останній рік життя композитора, своєрідно підсумували освоєння нових тембральних показників традиційних форм музики на початку XX сторіччя.

Обрис Сен-Санса композитора, як це відзначається дослідниками, визначився, насамперед, його внеском в оперний і концертно-симфонічний жанри. Опера «Самсон і Даліла», створена в 1876 р., названа М. Римським-Корсаковым «ідеалом оперної форми» [6, с. 920] і стала одним із самих знаменних творів, що формував світове визнання композитора. Фортепіанні концерти Сен-Санса (ix 5, особливо знаменитий i улюблений виконавцями № 2 g-moll 1868 р.) визначили його контакт із вершителями піаністичного мистецтва другої половини ХІХ століття - Ф.Лістом і А.Рубінштейном [6, с. 919].

Як засвідчують дати написання вищезгаданих і інших творів концертно-сольного прояву, вони, в основному, створені були в центральний період творчого шляху майстра. Звернення ж до камерноінструментальних жанрів сталося ближче до завершального періоду життя й діяльності великого музиканта. Фактично «прощальним» виявився цикл 1921 р. - Сонати для гобоя, кларнета, фагота й фортепіано.

Окрім названих Сонат для духових і фортепіано, К. Сен-Санс створив в 1872 і 1905 р. два твори цього жанру для скипки й фортепіано: op.32, c-moll, op.123 F-dur. Вище наводилися принизливі висловлення В.Бобровського з приводу оцінки сонатно-типологічної якості у представленні ї СенСансом. Однак практика інструментального виконавства свідчить про протилежне: Сонати великого французького композитора створили знаменний внесок у розвиток сонатної творчості в цілому.

Звертаємо увагу на той очевидний показник, що сонатна типологія в Сен-Санса кристалізувалася в процесі його освоєння сонатно-симфонічних композицій, причому, у явному схилянні до протонеобарочного синкретизму концерту й симфонії. А такого роду симбіоз типологій указує на наближеність до сонатного жанру, що визначив розвиток з нього, у якості спеціального різновиду, концертних і симфонічної «галузей». При цьому відзначається, що в цих концертно-симфонічних творах має місце картинно-ліричний принцип викладу, явно продовжуючи сферу французького естетизму в інструментальному мистецтві, що відтворює культ витонченого й умилительного початків, закладених рококо.

Так, відзначаючи зазначену властивість інструменталізму Сен-Санса, Е.Бронфин писав:

«У творах Сен-Санса панує світла поетична лірика, настрої радості, бадьорості, народжувані експресивною динамікою руху, соковиті жанрові замальовки, умиротворена споглядальність, шляхетна патетика, стриманий драматизм. ... Образи героїчного підйому, тривоги, збенетеження, суму - відносно рідкі. За своєю природою мистецтво Сен-Санса об'єктивне, логічне і ясне, інтелектуальний початок у ньому превалює над емоційним...» [6, с. 920].

Трактування фортепіанної сонати як «симфонізованої» композиції не становило прийнятного для французької традиції виміру змісту й образу. I найбільш різко цю позицію визначив К.Дебюссі, який писав, що бетховенським Сонатам «не вистачає» піанізму, що йому вони «здаються перекладенням 3 оркестру» [5, с. 142].

Оркестральність мислення в сонатах стала стереотипом пронімецької традиції трактування жанру, якому Франція наприкінці XIX століття протиставила протонеокласицизм і імпресіонізм-символізм, виведених багато в чому 3 позицій умилительного мистецтва рококо, яке склало антитезу мистецтву боротьби й протесту французького ж романтизму-реалізму першої половини й середини XIX ст. в особах Е.Делакруа, Г.Кюрбе, В.Гюго, Г.Флобера й ін.

У центрі інструментальної спадщини К. Сен-Санса стоїть його дивна «зоологічна фантазія», фактично, ансамблева концерт-соната для двох фортепіано, двох скрипок, альта, віолончелі, контрабаса, флейти, фісгармонії, ксилофона й челести. Такий склад співвідносимо з барочним concerto grosso, a загальна кількість номерів (14) утворить аналогію до сонат-сюїт для різних складів, іменованих у клавірному варіанті ordre, а в ансамблевому дивертисментом, капричіо й ін. Остання 3 названих 
типологій зазначена в «Капричіо на датські й російські народні теми для флейти, гобоя, кларнета й фортепіано» (ор. 79, 1887), структура й склад якого співвідносимо із сонатами-дуетами для струнних, духових і фортепіано.

«Карнавал тварин» К. Сен-Санса неодноразово ставав об'єктом виконавських зусиль музикантів Одеси, причому, у прояві виконань, ініційованих піаністами - А.Май, Н. Бузановою, О. і В. Щербаковими, підтриманих колективом «Гармоній світу» і його художнім керівником С.Шольцем. У їх виконанні традиціоналістські-ігрові прояви виразних можливостей ансамблевого інструменталізму СенСанса виявилися виділеними й підкресленими у творчій подачі цього яскраво національно вираженого мистецтва, у якому показовим для даної національної установки демонстративний інтелектуалізмартистизм стилістичного вибору виявився особливо культивованим і зберіганим.

По датах написання й сутності вибудовування кожної з названих композицій Сонат для гобоя, кларнета, фагота й фортепіано останні утворять деякий цикл, у якому лірико-елегійні мотиви панують, створюючи сукупний пасторальний колорит, невідривний від характеру тембрів кожного із заявлених духових інструментів.

Що стосується фортепіано, те тут композитор демонструє, як і у всіх написаних для даного інструмента композиціях, прихильність до французької традиції клавірності, яка виключає «рояльне всеохоплення», що так наполегливо відстороняв Дебюссі від французького розуміння піанізму. «Польотна» добірність пальцевої техніки, уникання тетральних протистоянь кантилени й туттійних ефектів «рояльного» звучання, органічне злиття піаністичної моторики із сукупністю моторно-пасажно трактованої звучності інших інструментів, що беруть участь в ансамблевому комплексі, - такий підсумок щодо естетичних нагромаджень французької ансамблевої традиції, концентрированно подаваної у відповідних творах Сен-Санса.

Висновки. Композитор виявився безпосереднім спадкоємцем салонного інструменталізму, у якому істотною $є$ фортепіанна участь у тім колориті клавірності, що представляє французький стиль фортепіанного мистецтва й живиться естетикою «легких» фортепіано епохи Реставрації. Для цього мистецтва показова антитеатральна манера відсторонення від безглуздостей і грубостей життя заради створення творчого «оазису» художнього служіння Красі. Этюдно-прелюдійна моторика займає провідне положення в техніці вираження, що усвідомлювалося в якості базового творчого показника у виконавському мистецтві музикантів Одеси, яка дала Україні творчий дует піаністів О.і В.Щербакових, ансамбль «Гармонії світу», ін. Останні спеціалізувалися на виконанні музики модерну й просимволістської художньої лінії, в якій твори К. Сен-Санса зіграли значну й самостійну роль.

\section{Jimepamypa}

1. Асафьев Б. Музыкальная форма как процесс. Москва-Ленинград, Музыка, 1971. 379 с.

2. Друскин М. История зарубежной музыки. Вторая половина XIX века. 5-е изд. Москва, Музыка, 1980. Вып. $4.528 \mathrm{c}$.

3. Лосев А. Эстетика Возрождения. М.: Мысль, 1982. 623 с.

4. Маркова Е. Проблемы музыкальной культурологии. Одесса, Астропринт, 2012. 164 с.

5. Мартынов И. Клод Дебюсси. Москва, Музыка, 1964. 280 с. 919-923.

6. Сен-Санс К. [ Е.Бронфин. Музыкальная энциклопедия в 6-ти томах. Т. 4. Москва, Сов.энциклопедия, 1978 С.

7. Соната [В. Бобровский Музыкальная энциклопедия в 6-ти томах. Гл.ред. Ю.Келдыш. Т. 5. Москва, Сов.энциклопедия, 1981. С. $193-200$.

8. Эрисман Г. де Французская песня. Москва, Сов.композитор, 1974. 152 с.

9. Roessler A., Hohl S. Der große Opernführer. Werke, Komponisten, Interpreten, Opernhäuser. Gütterslohn/ München, 2000. $608 \mathrm{~S}$.

\section{Reference}

1.Asafiev B. (1971). Music form as process. Books first and sekond. Moscow-Leningrad, Muzyka [in Russian]. [in Russian]

2. Druskin M. (1980). History of the foreign music. The Second half XIX age. 5 publ. Issue drink. 4. Moscow, Muzyka

3. Losev A. (1982). The aesthetics of the Revival. Moscow, Mysl [in Russian].

4. Markova E. (2012). The problem of music culturology. Odessa, Astroprint, [in Ukrainian]

5. Martynov I. (1964). Claud. Debussy. Moscow, Muzyka [in Russian]

6. Saint-Saëns C. (1978) [E. Bronfin The music encyclopedia in 6 volumes. Ed.-in-chief Yu. Keldysh.V. 4. Moscow, Sov.enciklopediya. pp. 919-923[in Russian].

7. Sonata [Bobrovskij V. (1981). Misical encyclopedia in 6 volumes. Editor-in-chief Ju.Keldysh. V. 5. Moscow, Sov.encyklopedija. pp. 193-200 [in Russian].

8. Erismann G. de (1974). French song. Moscow, Sov.kompozytor [in Russian].

9. Roessler A., Hohl S. Der große Opernführer. Werke, Komponisten, Interpreten, Opernhäuser. Gütterslohn/ München, 2000. p. 608. 